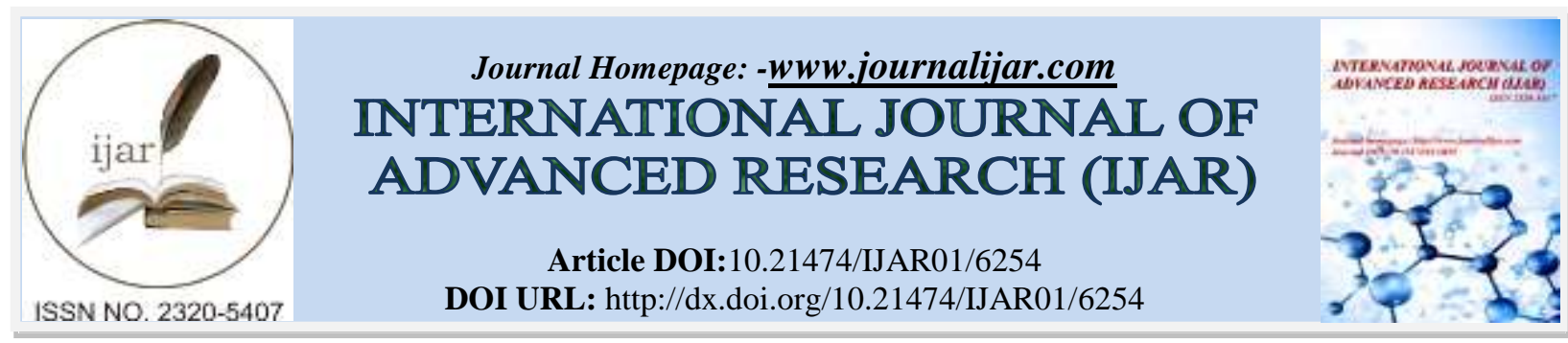

RESEARCH ARTICLE

\title{
AMOMUM PTEROCARPUM (ZINGIBERACEAE): A NEW RECORD IN THE FLORA OF MANIPUR.
}

\section{Ningombam Babyrose Devi ${ }^{1}$, Ajit Kumar Das ${ }^{2}$ and P.K. Singh ${ }^{3}$.}

1. Department of Ecology and Environmental Sciences, Assam University, Silchar, Assam.

2. Department of Ecology and Environmental Sciences, Assam University, Silchar, Assam.

3. Centre for Advanced Studies in Life Sciences, Manipur University, Chanchipur, Imphal, Manipur.

\section{Manuscript Info}

Manuscript History

Received: 08 November 2017

Final Accepted: 10 December 2017

Published: January 2018

Key words:-

flora, Manipur, new report, Атотит

pterocarpum.

\section{Abstract}

Amomum pterocarpumThwaites.a native of Sri Lanka has been reported for the first time from Manipur. It has a distribution in India and as well as Sri Lanka. Detailed description and illustration of the plant is provided. The plant was found growing with a small population as undershrub in moist evergreen forest of Imphal East district, Manipur.

\section{Introduction:-}

The Zingiberaceae is the largest of the eight families of the order with 53 genera and over 1200 species (Kress, 1990, Kress et al., 2002). The genus Amomum Roxb.is the second largest genus of the family Zingiberaceae recorded with 150 species (Tripathi et al., 1999). Amomum subulatum was described in detail with an excellent illustration for the first time (Roxburgh, 1820a) in his 'Plants of the Coast of Coromandel' and in 'Flora Indica' (Roxburgh, 1820b). A. subulatum is indigenous to moist deciduous and semi-evergreen forests of sub-Himalayan tracts.

Manipur is situated in the north eastern part of India sharing international boundary with Myanmar. It falls in the Indo-Burma biodiversity hotspot and has its own unique bio-resources of flora and fauna. An extensive survey was conducted in Imphal East District of Manipur, North-east India in the month of April, 2015. The Amomum specimen was observed for the first time from Imphal East district. The area is located at $24^{0} 49^{\prime} \mathrm{N}$ and $94^{0} 04^{\prime} \mathrm{E}$ at an altitude of $1020 \mathrm{~m}$ above msl. A detailed study was undertaken with the various floras and herbaria and is subsequently identified as Amomum pterocarpum Thwaites. The collection forms a new distributional record in the Zingiberaceae flora of Manipur.

Key to species:-

Spike shortly peduncled, capsule globose, fruit irregular. 4.A. pterocarpum

\section{Taxonomic treatment:-}

Amomum pterocarpum Thwaites. Enum. P1. Zeyl. 317. 1861. Hook.f. Fl. Brit. India 6. 241. 1892; Lakshminarasimhan in Sharma et al. Fl. Maharashtra State Monocot 68. 1996. 


\section{Description:-}

Plant perennial, aromatic, rhizomatous.Pseudostem elongate 1- $2.5 \mathrm{~m}$ tall. Leaf sheath present, large, oblonglanceolate, adaxiallypubescent.Inflorescence arising from base of leafy shoot. Leaves $45-50 \times 12-17 \mathrm{~cm}$. Spikes $7.5 \mathrm{~cm}$, globose, shortly peduncled. Bracts imbricate, persistent, outer bract oblong, glabrous. Flowers white, showy. Calyx tube $2.6 \mathrm{~cm}$ long, 3 toothed. Corolla glabrous, shiny, white in colour. $2.5 \mathrm{~cm}$ x $8 \mathrm{~mm}$. labellum clawed 4 x 3 $\mathrm{cm}$, conspicuous, yellow at center, white margin, lateral staminodes reduced to short appendages, anther crest semilunar, 3 lobed. Filament well developed, $5 \mathrm{~cm}$ long. Fruit capsule, irregular, smooth.

Fl. \& Fr. - April - October

\section{Conservation status - Least concern}

Uses - Fruit masticator, spice and condiments, applied in toothache.

Established report- Seeds used as a stomachic, gums problem and kidney stones

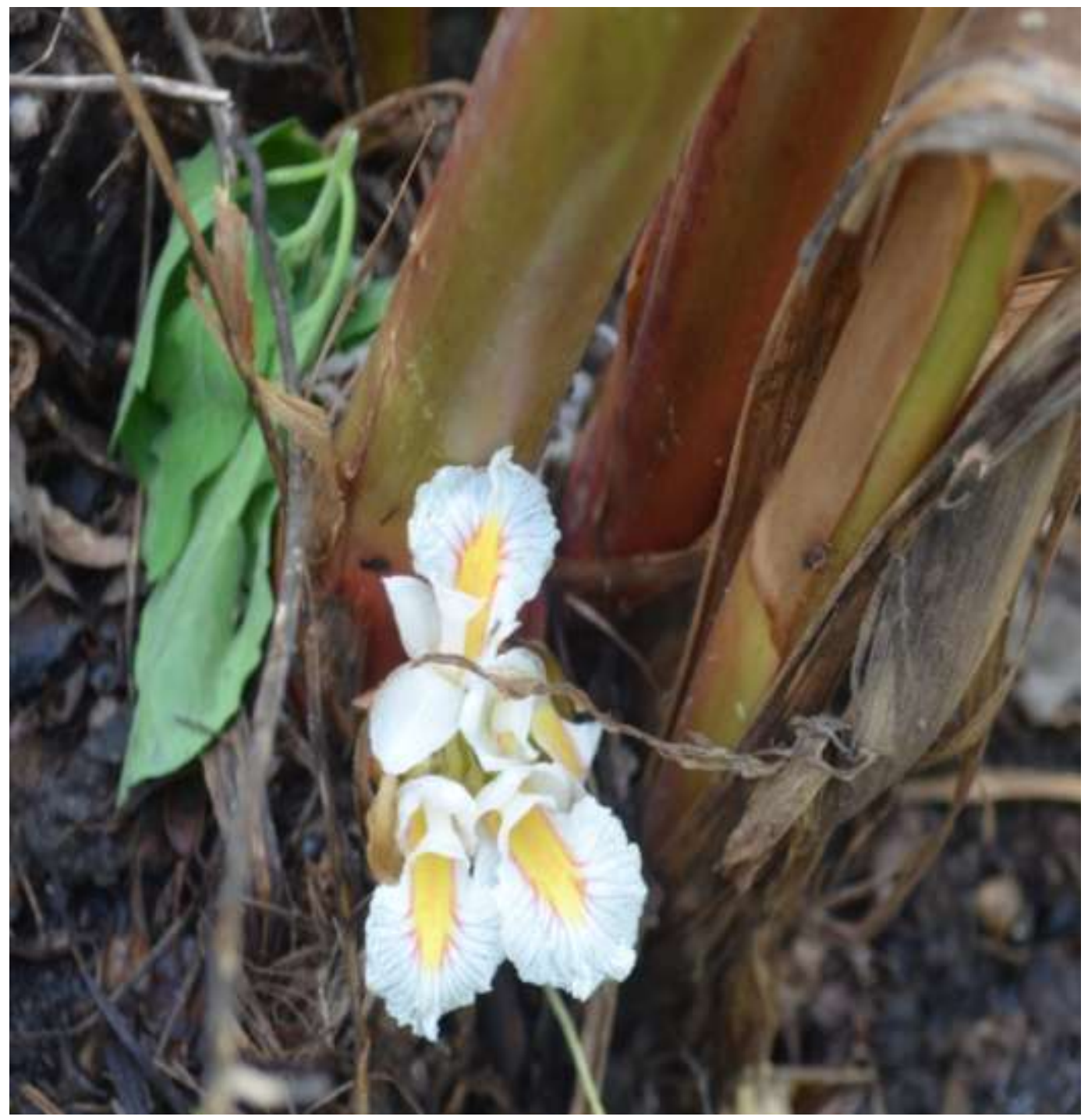




\section{Photo: AmomumpterocarpumThwaites. in natural habitat}
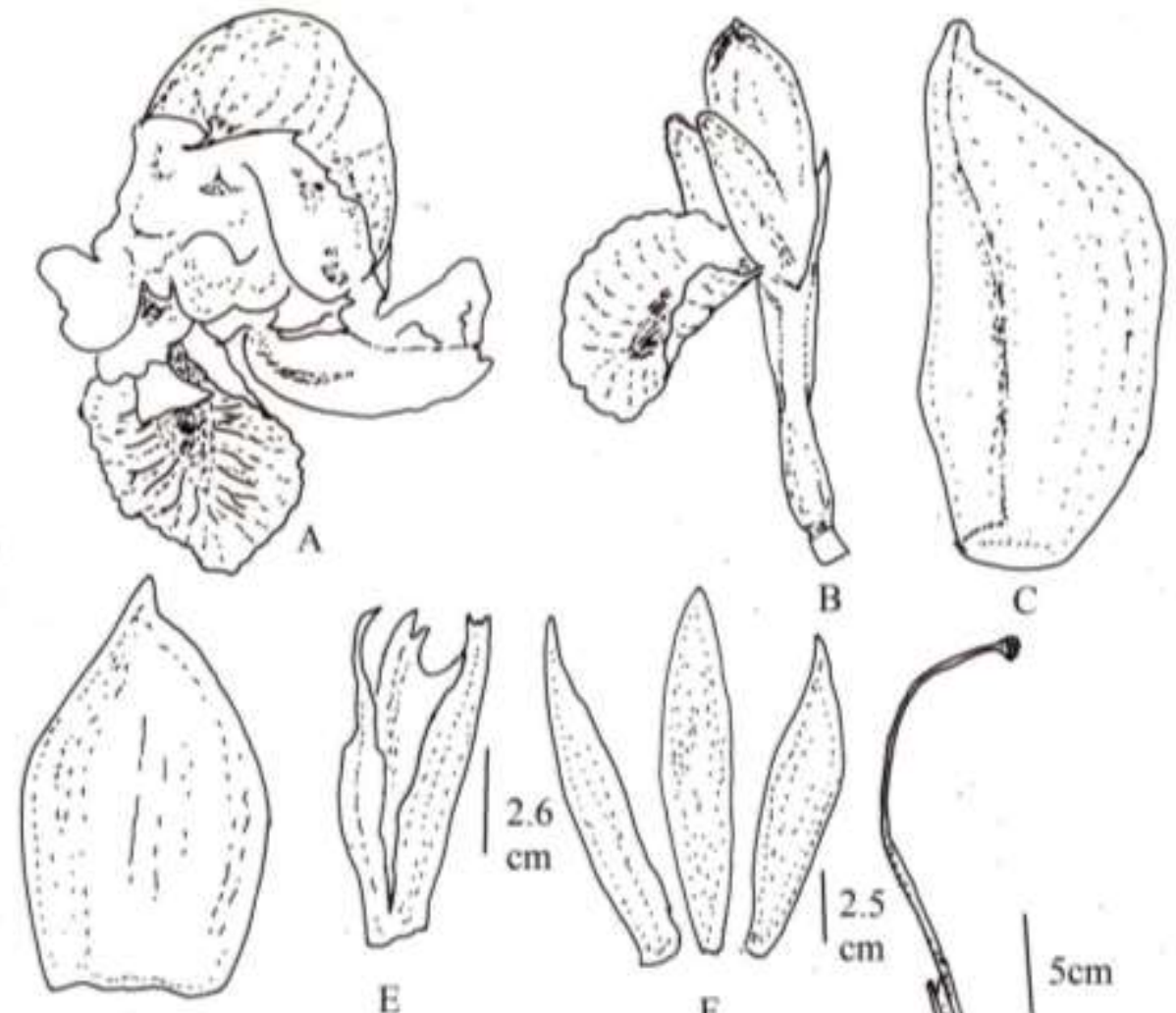

D

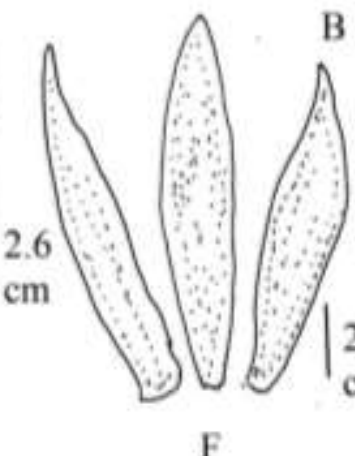

B $\quad \mathrm{C}$
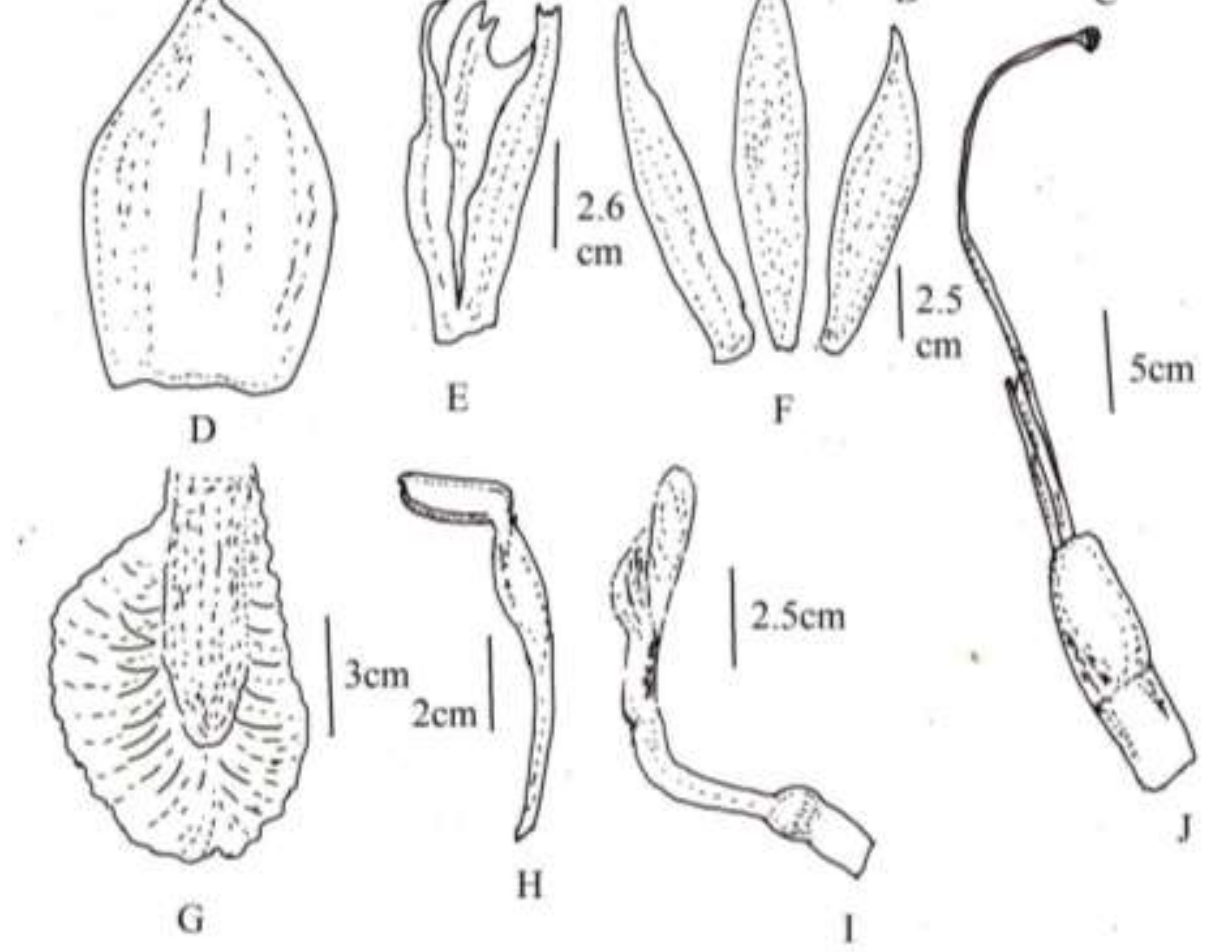

Fig. A. Amomum ptenocarpum Thwaites. A. inflorescence B, single flower C. bract D. bracteole E. calyx F, corolla lobes G. labellum H. stamen I. labellum with ovary J. gynoecium with epigynous glands.

\section{Discussion:-}

Encroachment of the forest area is a serious problem facing towards the destruction of the forest. Another major threat for the destruction of forests includes burning down and felling of trees for charcoal following shifting and jhum cultivation which decreases the vegetation and flora of the area resulting in loss of habitat of the plants as well as microorganisms in soil. 
All the plant species under this family are ethnobotanically important, mentioning few are Hedychium coronarium, Alpinia galanga, Curcuma angustifolia, Zingiber officinale which are consumed as food, as medicine, as well as it has a significant importance in performing our ritual duties in Manipur. The Composition of oils in rhizomes and leaves of Amomum pterocarpum Thwaites.were studied. Thus, the conservation practice of this plant species is the high time to start with the conservation program.

\section{References:-}

1. Deb, D.B. (1961). Monocot and Dicot plants of Manipur .Territory Bull. Bot.Surv. India. 3: 115-138.

2. Deb, D.B. (1983). The flora of Tripura state. Today and Tomorrow Publication, New Delhi. 2: 366-380.

3. Duthie, J.F. (1903) and (1922). Flora of the Upper Gangatic Plant and the adjacent Siwalik and Himalayan trades. Vol. I-II, Govt. of India. Central Publication Branch, Calcutta.

4. Hooker, J.D. (1872-1892).The Flora of British India, Vols.1-7.London.

5. Kress, W. J. Prince, L.M. and Williams, K.J. (2002). The phylogeny and a new classification of the gingers (Zingiberaceae): evidence from molecular data. American J. Bot. 89: 1682-1696.

6. Roxburgh, W. (1820a). Plants of the Coast of Coromandel. Vol 3. Mission Press, Serampore.

7. Roxburgh, W. (1820b). Flora Indica Vol. 1 W. Bulmer and Co., London.

8. Sabulal, B., George, V. and Dan, M. (2007). Composition of rhizomes and leaf oils of Amomum pterocarpum Thwaites. The Journal of Essential oil Research. 19(1). 23-25.

9. Tripathi, S. and Prakash, V. (1999). A new species of Amomum Roxb. from Meghalaya, India. Rheedea 9 (2): 177-180. 